

\title{
Export-Total Factor Productivity Growth Nexus in East Asian Economies
}

\author{
Hailin Liao, Xiaohui Liu
}

\section{To cite this version:}

Hailin Liao, Xiaohui Liu. Export-Total Factor Productivity Growth Nexus in East Asian Economies. Applied Economics, 2009, 41 (13), pp.1663-1675. 10.1080/00036840601032193 . hal-00582060

\section{HAL Id: hal-00582060 https://hal.science/hal-00582060}

Submitted on 1 Apr 2011

HAL is a multi-disciplinary open access archive for the deposit and dissemination of scientific research documents, whether they are published or not. The documents may come from teaching and research institutions in France or abroad, or from public or private research centers.
L'archive ouverte pluridisciplinaire HAL, est destinée au dépôt et à la diffusion de documents scientifiques de niveau recherche, publiés ou non, émanant des établissements d'enseignement et de recherche français ou étrangers, des laboratoires publics ou privés. 


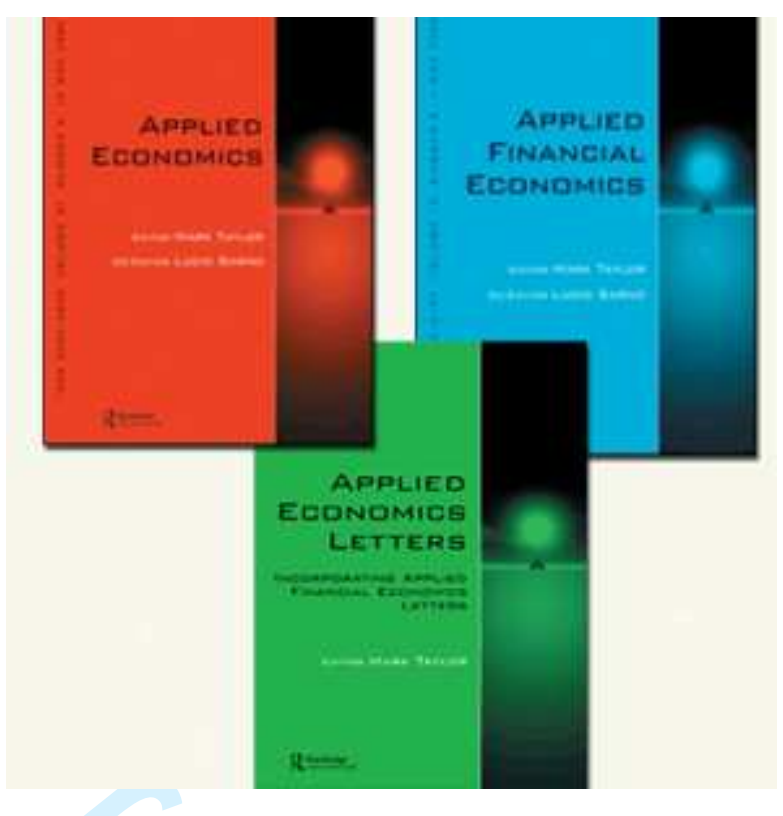

\section{Export-Total Factor Productivity Growth Nexus in East Asian Economies}

\begin{tabular}{|c|c|}
\hline Journal: & Applied Economics \\
\hline Manuscript ID: & APE-06-0052.R1 \\
\hline Journal Selection: & Applied Economics \\
\hline $\begin{array}{r}\text { Date Submitted by the } \\
\text { Author: }\end{array}$ & 21-Sep-2006 \\
\hline Complete List of Authors: & $\begin{array}{l}\text { Liao, Hailin; Loughborough University, Economics } \\
\text { Liu, Xiaohui; Loughborogh University, Business School }\end{array}$ \\
\hline JEL Code: & $\begin{array}{l}\text { D24 - Production|Capital and Total Factor Productivity|Capacity }< \\
\text { D2 - Production and Organizations < D - Microeconomics, O40 - } \\
\text { General < O4 - Economic Growth and Aggregate Productivity < O - } \\
\text { Economic Development, Technological Change, and Growth, O11 - } \\
\text { Macroeconomic Analyses of Economic Development < O1 - } \\
\text { Economic Development < O - Economic Development, } \\
\text { Technological Change, and Growth, F43 - Economic Growth of Open } \\
\text { Economies < F4 - Macroeconomic Aspects of International Trade } \\
\text { and Finance < F - International Economics }\end{array}$ \\
\hline Keywords: & $\begin{array}{l}\text { TFP, exports, Bound tests, lag-augmented VAR, East Asian } \\
\text { economies }\end{array}$ \\
\hline
\end{tabular}




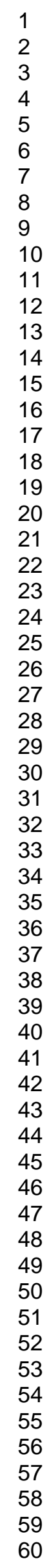

\section{SCHOLARONE ${ }^{m}$ \\ Manuscripts}

7

25

26

27

29

30

31

33

34

35

36

37

38

41

42

43

45

46

47

48

49

51

52

53

54

55

57

58

59

60 


\title{
Export-Total Factor Productivity Growth Nexus in East Asian Economies
}

\author{
Hailin Liao ${ }^{1}$ \\ Department of Economics \\ Loughborough University \\ Leicestershire LE11 3TU \\ Tel: 01509222727 \\ Fax: 01509223910 \\ Email: H.Liao@lboro.ac.uk \\ Xiaohui Liu \\ Business School \\ Loughborough University \\ Leicestershire LE11 3TU
}

\begin{abstract}
Despite increasing interest in the relationship between trade and macroeconomic performance in development economics, very limited studies have been conducted on the causal links between exports and productivity growth in Asian economies. This paper examines empirically the interplay between exports and productivity growth for eight East Asian economies in a multivariate framework by applying bound tests and modified Wald tests. The results indicate that causality is bi-directional in the case of Korea, Singapore and Taiwan, while unidirectional from productivity to exports for Mainland China, Hong Kong, Indonesia, Malaysia and the Philippines. These findings provide little support for the conventional export-led growth hypothesis.
\end{abstract}

\section{KEY WORDS}

TFP; exports; Bound tests; lag-augmented VAR; East Asian economies

\footnotetext{
${ }^{1}$ The corresponding author.
} 


\section{Export-Total Factor Productivity Growth Nexus in East Asian Economies}

\section{Introduction}

Empirical investigation of the causal link between exports and growth is an important theme in trade and development literature. In particular, the rapid growth of many East Asian economies over the last four decades has stimulated much debate about sources of economic growth. The extend to which the East Asia's success is attribute to protectionist policies on the one hand and outward oriented policies on the other has been the focus of attention. A large number of empirical studies have been carried out on causality between trade and growth for this region (Hsiao, 1987; Chen and Tang, 1990; Ahmad and Harnhirun, 1995; Islam, 1998; Kwan et al., 1996; 1999; Liu, et al., 2002; Jin, 2004; Awokuse, 2006; Yao, 2006). These studies have shed some light on the issue and provided some useful insights regarding the evaluation of trade and development strategies. However, previous studies have focused on the link between exports and GDP or output growth explicitly, or the relationship between exports and labour productivity growth (Marin 1992; Yamada 1998; Thangavelu and Rajaguru 2004).

What is absent in this area is an explicit assessment of the relationship between exports and technological progress represented by growth in total factor productivity (TFP) ${ }^{2}$ although the possibility has already been postulated in development theory (Marin, 1992; Ben-David and Loewy, 2003). Partial productivity measures have long been criticized for their incomplete picture of performance, thereby causing misleading analysis. They are also subject to the input substitution effect. It would be difficult to distinguish whether labour productivity being high in a sector is because of a high degree of technological efficiency or because of a large stock of

\footnotetext{
${ }^{2}$ The World Bank (1993) supported the view that the promotion of exports had been a significant source of rapid productivity change through greater access to best practice technologies. However, this proposition has been strongly criticized by Rodrik (1995) and others on the basis of empirical work by Young (1995). The main argument was that substantial TFP growth was not observed (Dessus, 1999). However, results of many previous studies which tried to relate GDP growth to the growth of trade may be biased due to a simultaneity problem.
} 
physical capital, given that labour productivity fails to capture all of the influences on productivity. TFP growth, on the other hand, measures the ratio of output to the sum of all basic inputs, and therefore mitigates the impact of factor substitution and scale economies. In addition, TFP evaluates technological progress and constitutes a measure of the efficiency with which all the factors of production are employed. Therefore, using TFP instead of labour productivity allows us to assess the impact of exports on technological progress. This study aims to fill the gap by evaluating the causal links between exports and productivity growth in East Asian economies.

Besides using TFP instead of labour productivity, we adopt the frontier approach to calculate the TFP, which enables us to overcome some drawbacks of the non-frontier measures of productivity, and represents an improvement over the previous studies (see Appendix A). The most important difference between the frontier approach and the traditional growth accounting method lies in one assumption i.e. the existence of an unobservable and idealized production possibility frontier with production-unit specific, one-sided deviation from the frontier which explicitly allows for inefficiency (Farrell, 1957; Lovell, 1993; Kumbhakar and Lovell, 2000).

We also apply different empirical methods to capture the nature of the links between these variables, which represents one of the contributions of our study. Bounds testing and modified Wald (MWALD) tests, both of which avoid the pre-testing problem in possible nonstationary time series, will be applied to examine causal links. The paper is structured as follows. Section 2 discusses the theoretical foundations for possible bi-directional linkage between exports and TFP growth. Section 3 introduces the methodology and data used in the study, while the following section presents and analyses empirical results. Section 5 concludes with policy implications. 


\section{Theoretical Links between TFP and Exports}

The new endogenous growth models establish the links between long-run growth and technological progress, and provide a framework in which trade can permanently increase the rate of growth in the host country through technology transfer, diffusion, and spillover effects. Romer (1993) points out that one benefit that trade brings is access to new ideas. Grossman and Helpman (1991) have constructed a theoretical model to show formally that trade in goods serves as a conduit for knowledge flows between countries. These flows in turn serve to increase the productivity of capital and labour, and hence the growth rate of per capita output. In addition, the human capital building model as presented by Lucas (1988) may suggest that trade could enable inter-country technology transfers.

Although trade is important for economic growth, the causal link between them is not necessarily unidirectional as productivity growth can also influence trade. Theoretical justifications for reverse causation from growth to trade have long been discussed in development literature (Kanamori, 1968; Diaz-Alejandro, 1975; Kravis, 1970; Findlay, 1984). It is argued that economic growth via increased productivity or reduced unit costs is expected to act as a stimulus to exports (Kaldor, 1967). Jung and Marshall (1985) suggest that internal growth mechanisms better explain export growth rather than the reverse. In new trade theory, the market structure and output expansion may trigger significant changes in exports through a process of “cumulative causation" (Venables, 1996).

Given the possible bi-directional relationship between exports and TFP growth postulated by the theories, the issue becomes empirical and can be verified through statistical tests. Attempts have been made to establish a causal link between exports and TFP growth empirically. Previous studies in this area fall roughly into two groups: cross-country/sectional investigations and individual country analysis over time. The former can be further categorised into rank 
correlation coefficient studies represented by the Balassa's (1978) work, simple OLS regression between exports and output, and using production function approaches based on either the growth equation or Feder's (1982) two-sector (exports and non-exports) model. The general conclusion from cross-country studies is that high levels of economic growth are significantly associated with high levels of export growth, though there are exceptions.

The main arguments against cross-sectional data analysis are that 1) it implicitly imposes or assumes a common economic structure and identical production technology across countries which are most unlikely to be held; 2) correlation does not necessarily imply/prove the direction of causality; 3) exports, via national accounting identity, are themselves part of national production. Therefore, any export growth studies which do not consider the endogenous nature of the growth process may be subject to simultaneity and specification biases (Greenaway and Sapsford, 1994).

The critiques for the cross-sectional studies have led to the use of time-series data for causality tests, but the results are inconclusive. Using a regression equation similar to the sources of growth equation, with trade being specified as the growth of exports, about 20 time-series studies reached nearly identical results as cross-sectional studies (e.g Ram, 1987; Sengupta and Espana, 1994; Kwan et al., 1996; Greenaway and Sapsford, 1994; Greenaway et al., 1997; Van den Berg, 1997; Amin Gutierrez de Pineres and Ferrantino, 1999; Vohra, 2001). However, the size of the effect is sharply reduced when a quarter of these estimation procedures are adjusted in accordance with unit root test results. For example, the average value of the real export variable goes down from 0.26 to 0.08 (Lewer and Van den Berg, 2003). More interestingly, many researchers have found evidence that trade generates more growth in developed economies than in developing countries. The probable reasons for the differences in coefficient value between high income and low income countries are attributed to low adsorptive capacity to foreign technology in developing countries (Coe et al., 1997). 
Clearly, further time-series analysis is called for due to the following reasons. First, the simple formation of Granger causality regression lacks a theoretical foundation, and the twovariable relationship between exports and growth is examined in isolation; therefore, omitted variable bias (e.g. import variable) is likely to occur (Riezman et al 1996). Second, there are some problems in relation to estimation procedures. For example, the lag length is selected arbitrarily in some previous studies (Jung and Marshall, 1985). Moreover, F-test statistics for causality tests have been applied. It is now well established that the F-test statistics are not valid if times series are integrated (Toda and Yamamoto, 1995; Zapata and Rambaldi, 1997). Finally, there are limited studies on the causality between TFP and exports, probably due to data unavailability. Extending previous work in this area, the present study attempts to estimate the complex interaction between exports and TFP growth in a multivariate framework (including import variable) for selected Asian economies using bound tests and MWALD tests.

\section{Empirical Methodology and Data}

\section{Bounds Testing}

The concept of Granger causality is well known, and the test for causality is straightforward with stationary data. However, if the series are non-stationary, testing the causal link between variables in their levels leads to statistics which do not have the relevant F-distribution under the null hypothesis (Toda and Phillips, 1993). One way to deal with this is to apply a cointegration approach. However, this approach is typically affected by pre-tests on unit roots and the cointegration rank. The power of such pre-tests is low, and subsequent tests of long-run relations and causality conditioned on these pre-tests could induce severe pre-test bias ${ }^{3}$. Pesaran et al.

\footnotetext{
${ }^{3}$ A potential weakness of the techniques for cointegration (for example, Engle and Granger procedure and Johansen's procedure) is that they require certain pre-testing for unit roots and also that the underlying time series to be integrated are of the same order. If this is not the case, the evaluation of the long-run relationship may not be performed within the context of cointegration, at least in the two-variable context.
} 
(2001) propose bound tests as one way of avoiding pre-test bias. The bounds arise from two polar cases, namely joint stationarity of all variables, and non-stationarity of all variables, with cointegrated cases being intermediate. The tests are formulated via the following regression:

$$
\Delta y_{t}=c_{0}+c_{1} t+\pi_{1} y_{t-1}+\pi_{2} x_{t-1}+\sum_{i=1}^{a} \gamma_{i} \Delta y_{t-i}+\sum_{j=0}^{b} \delta_{j} \Delta x_{t-i}+\varepsilon_{t}, \mathrm{t}=1,2 \ldots
$$

In equation (1), $\mathrm{y}_{\mathrm{t}}$ is the dependent variable; $\mathrm{x}_{\mathrm{t}}$ is a vector of independent variables; $\pi_{1}$ and $\pi_{2}$ are the respective long-run multipliers for $\mathrm{x}$ and $\mathrm{y} ; \gamma$ and $\delta$ represent the short-run dynamic coefficients ${ }^{4} ; \mathrm{c}_{0}$ is the drift component; $\mathrm{c}_{1}$ is the time trend and $\varepsilon_{\mathrm{t}}$ is a zero mean stationary process (model V in Pesaran et al. 2001). If there is no deterministic trend but an intercept (model III in Pesaran et al 2001), the model can be defined as ${ }^{5}$

$$
\Delta y_{t}=c_{0}+\pi_{1} y_{t-1}+\pi_{2} x_{t-1}+\sum_{i=1}^{a} \gamma_{i} \Delta y_{t-i}+\sum_{j=0}^{b} \delta_{j} \Delta x_{t-i}+\varepsilon_{t}
$$

\section{MWALD Approach to Causality}

The modified Wald (MWALD) test developed by Toda and Yamamoto (1995) and further developed by Dolado and Lutkepohl (1996) is applied to investigate long-run causalities as this approach does not require knowledge of cointegration properties of the system 'so long as the order of integration of the process does not exceed the true lag length of the model' (Toda and Yamamoto, 1995).

We consider a trivariate system, namely $\mathrm{Y}$ (productivity growth in manufacturing), $\mathrm{X}$ (export growth) and Z (import growth), in the following trivariate VAR system.

$$
\left[\begin{array}{c}
y_{t} \\
x_{t} \\
z_{t}
\end{array}\right]=A_{1}\left[\begin{array}{c}
y_{t-1} \\
x_{t-1} \\
z_{t-1}
\end{array}\right]+A_{2}\left[\begin{array}{c}
y_{t-2} \\
x_{t-2} \\
z_{t-2}
\end{array}\right]+\ldots A_{k}\left[\begin{array}{c}
y_{t-k} \\
x_{t-k} \\
z_{t-k}
\end{array}\right]+\ldots+A_{\left(k+d_{\max }\right)}\left[\begin{array}{c}
y_{t-\left(k+d_{\max }\right)} \\
x_{t-\left(k+d_{\max }\right)} \\
z_{t-\left(k+d_{\max }\right)}
\end{array}\right]+\left[\begin{array}{c}
e_{y} \\
e_{x} \\
e_{z}
\end{array}\right]
$$

\footnotetext{
${ }^{4}$ Due to the uncertainty whether $\mathrm{x}$ is the long-run forcing variable for $\mathrm{y}$, we exclude the current value of firstdifferenced $\mathrm{x}$ in the regression of equation (1) and (2), according to Pesaran \& Pesaran (1997).

${ }^{5}$ For a detailed discussion of the model, see Pesaran et al. (2001).
} 
There are two reasons for an import variable to be included. First, bivariate systems are often criticised as incomplete, omitting potentially important variables. Failure to account for omitted variables can lead to misleading causal ordering, and yield biased results. Second, Riezman et al. (1996) have pointed out that 'standard methods of detecting export-led growth using Granger-causality tests may give misleading results if imports are not included'. Hence, import growth in the trivariate system is treated as an auxiliary variable for 'indirect measures of technological adoption' (Coe et al., 1997). This specification allows us to investigate whether the causality results would remain the same by switching from the bivariate system to a trivatriate one $^{6}$. Hence, we study only direct causality between exports and TFP growth by controlling the possible indirect causality running from imports to productivity.

\section{Robustness Check}

We also employ more conventional methods to check the robustness of our results from the methods discussed above. ADF unit root tests are performed to determine the order of integration of the variables ${ }^{7}$. As far as the causality is concerned, the VECM is performed in order to compare its results with those from MWALD tests.

\section{Data}

\footnotetext{
${ }^{6}$ Since trivariate tests incorporate more information than bivarite ones, the causal inferences drawn appear more reliable.

${ }^{7}$ Results are available upon request.
} 
The sample used in this study consists of the first and second wave of newly industrialised economies (NIEs) in East Asia, notably Hong Kong, Singapore, South Korea, Taiwan, Indonesia, Malaysia and the Philippines. In addition, China, as a large developing country in the region, is also included. TFP growth rates in manufacturing sectors calculated in Liao et al (2006) using a stochastic frontier approach are weighted by their share in the manufacturing value-added in the current year in order to obtain annul aggregate data for each economy ${ }^{8}$. Data for exports and imports are derived from World Development Indicators (2000) and various annual reports from the Asian Development Bank. All the data are in real terms, adjusted to 1990 prices. For example, the data for exports and imports were adjusted to the 1990 prices using their respective export and import price indices. When price indices were not available, GDP deflators were used. The sample period is from 1963 to 1998 for most of the sample economies, but from 1981 to 1998 for China, due to data unavailability.

\section{Empirical Results}

\section{Results from Bound Tests}

The key step in bound tests is to determine the appropriate lag length. A trade-off must be considered between choosing $\mathrm{p}$ sufficiently small so as to avoid the problems of overparameterisation in small samples, and sufficiently large to avoid serial correlation in the residuals. We follow the approach of Pesaran et al (2001) to estimate the conditional ARDLerror correction model by the OLS, with and without a linear time trend, and determine the appropriate lag length by a combination of Schwarz Bayesian Criterion $(\mathrm{SBC})^{9}$ with the maximum lag length set to $\mathrm{T}^{1 / 3}$. Various diagnostic tests are also performed such as residual

\footnotetext{
${ }^{8}$ Detail on the frontier approach to TFP calculations applied in this paper is presented in Appendix A.

9 The SBC usually selects a lower lag order when taking the small sample into consideration. In our case, the approach we employed is similar to Hendry's general-to-specific approach, where the rationale is to re-estimated the basic model by dropping the lagged variables with insignificant parameters from the system.
} 
serial correlation, functional form and normality. We also employ the bond tests to detect which variable (productivity or exports) is the long-run forcing variable.

\section{Insert Table 1}

The results of the bounds testing presented in Table 1 suggest the existence of a long-run relationship between TFP growth and exports in all economies in question. It appears that high TFP growth leads to an increase in exports in the case of China, Indonesia, and the Philippines, given that the calculated F-statistics are greater than the upper level of the critical value bounds at the conventional significant level. Reverse causation running from exports to productivity growth exists in the case of Korea, Singapore and Taiwan. Earlier conventional views on East Asia's success have frequently stressed export orientation as a major source of growth. However, the preliminary results from our study provide evidence that exports might have played a smaller role toward productivity growth than was previously thought, at least in some sample economies.

There are also some inconclusive results from the ARDL cointegration test based on the F-statistics. For example, the results for Hong Kong and Malaysia are quite mixed. As BahmaniOskooee and Miteza (2002) argue, a more efficient way of establishing cointegration is to estimate the entire equation (1) and (2), and check the significance of the error-correction term (ECT) since the long-run effects are reflected in the significant coefficient obtained for the lagged ECT. We adopt this approach to compare whether the results are consistent (Appendix table 1B). Most of the coefficients of ECT are statistically significant with the expected negative sign, confirming the results for cointegration from the F-test. We also estimate the long-run coefficients for the case where a significant long-run relationship was found (Appendix table 2B). 
Table 2 summarises these two tests for the long-run relationships using F-statistics and ECT representation; the latter only shows the results that are inconclusive in the F-test as a supplement. Taken together, the results from these two tests are consistent, indicating that the long-run relationship from productivity growth to export performance exists in the cases of Mainland China, Hong Kong, Indonesia, Malaysia and the Philippines, and from exports to productivity growth in Korea, Singapore and Taiwan.

\section{Causality Analysis}

\section{MWALD Test for Causality}

The same approach is adopted for selecting the lag length when testing causality. That is, the optimal lag order (k) is selected by AIC and/or SBC statistics from unrestricted VAR (k) estimated by the OLS over the same sample, with the maximum lag length set to $T^{1 / 3}$. One of the criteria for lag length selection is to eliminate autocorrelation. However, we cannot take the risk of over-parameterization by choosing a higher order for the VAR, given that our sample period is relatively short. Hence, the causality tests are performed by estimating VAR $(k+1)$, where $\mathrm{k}$ is the optimal lag order in the VAR as the variables are, at most, I(1) processes.

Rambaldi and Doran (1996) proved that the MWALD method for testing Granger nocausality can be computationally simple by running a Seemingly Unrelated Regression (SUR) in several build-in econometric packages, such as Shazam and Microfit ${ }^{10}$, which use the F-statistic involving coefficients of lags 1 through $\mathrm{k}$. The results from the MWALD test are summarised in Table 3. It can be seen that the results are sensitive to model specifications (i.e. with and/or without linear trend and constant) which will affect the inferences drawn from the causality tests.

\footnotetext{
${ }^{10}$ The tests are performed using the SUR routine in both software packages for comparison. The results are quite similar. However, as Microfit4.0 utilizes maximum likelihood estimation (MLE) rather than generalised least square (GLS) used in Shazam, the estimated standard errors for the MLE are generally smaller and therefore test statistics are smaller. We only report test statistics and rejection p-value from Shazam for simplicity.
} 
In order to avoid contradictory results, we follow Mills' (1998) approach and use information criteria (SBC here) to select jointly the lag order of the unrestricted VAR and the order of any additional trend polynominal to determine the optimal models, and these are shaded in Table 3.

Insert Table 3, here,

The evidence shows that the export-led TFP growth exists in Korea and Singapore, while the productivity-led exports appear to be likely in China, Hong Kong, Indonesia, Philippines and Malaysia. There is bi-directional causality in Taiwan, implying that exports and productivity growth have reinforced each other. For the second-tier East Asian economies, such as Indonesia, Philippines and Malaysia, these results suggest that the productivity growth does not respond to lagged changes in exports. This is contradictory to the conventional argument that openness, especially exports, trigged economic and productivity growth in East Asia. The evidence provides little support for the export-led growth hypothesis. In contrast, productivity is found significant in explaining the future path of exports, confirming the productivity-led export hypothesis. Hence, our results support the traditional argument that improvements in productivity growth translate into greater competitiveness in export growth in the standard Ricardian model. It may be the case that the economy improves its productivity through technology spillovers from advanced economies according to the endogenous growth theory, and this enhanced productivity further stimulates exports. On the other hand, the export-led productivity scenario found in the first-tier East Asian economies, with the exception of Hong Kong, provides support for outward-oriented trade strategies under which competition in export markets could lead to greater efficiency as local firms face greater competition from foreign firms. 


\section{VECM and Standard Granger Causality}

We also perform a standard Granger causality test augmented with an appropriate ECT taken from the appropriate long-run relationship to detect causality between productivity growth and exports. Concerning the choice of optimal lag length, we adopt Akaike (1969)'s final prediction error $(\mathrm{FPE})$ criterion. The FPE can be calculated as $(\mathrm{SER})^{2}(\mathrm{~N}+\mathrm{k}) / \mathrm{N}$, where SER stands for the standard error of the regression, $\mathrm{k}$ is the lag length used in the regression and the optimal lag length corresponds to the minimum FPE, taking into account residual serial correlation. Intuitively, the test of whether exports Granger-cause productivity growth or vice versa is simply a test of the hypothesis that the coefficients of lagged independent variables are all equal to zero and/or the lagged ECT is significantly different from zero.

\section{Insert Table 4}

The results presented in Table 4 indicate that there is a bi-directional causality between exports and productivity growth in Korea, Singapore, Taiwan and Malaysia. The channel of influence from exports to productivity is the significant ECT for Korea and Singapore, and both short-run and long-run effects exist in Taiwan. Conversely, there is short-run reverse causation from productivity to export performance for Singapore and Taiwan, and long-run causation for Korea, based on the adjustment toward long-run equation. Causality is unidirectional, running from productivity to exports, for China, Hong Kong, Indonesia, Malaysia and the Philippines. Both long-run and short-run causal links exist in Hong Kong, whereas only long-run causality is found in the remaining four economies.

Since there are some arguments ${ }^{11}$ that the standard Granger-causality test is very sensitive to the choice of the lag length, we perform the tests with lag length from $k=1$ to $k=4$ to see 


\section{Conclusions}

Insert Table 5, here

whether the lag length selected will affect the results considerably (results not report here). However, the results in general do not change markedly across lag lengths. Therefore, the specification, using the ECT derived from model V or model III of ARDL-cointegration test with various lag lengths, does not affect the results from causality tests in our study. Taken together, the results obtained from both MWALD and VECM tests are consistent (Table 5), thus providing robust evidence on the causal link between exports and TFP growth for the sample economies.

This paper investigates empirically the linkage between exports and TFP growth for eight East Asian economies by applying ARDL bounds tests and MWALD tests. Our main findings are that 1) the long-run relationship between productivity growth and export performance exists for all economies under investigation; and 2) causality is bi-directional in the case of Korea, Singapore and Taiwan, while unidirectional from productivity to exports for the rest, which provides little support for the export-led growth hypothesis.

The diversity of results across countries/economies undoubtedly reflects a wide variety of outward orientation strategies (especially exports) implemented across the region. It is also probably related to the fact that these economies have different patterns and are at the different stage of development.

In some economies, export expansion and TFP growth go hand in hand, suggesting that exports and TFP growth are integral elements in the growth process. However, in other economies, TFP growth has played a more important role in promoting exports, as found at firm

\footnotetext{
${ }^{11}$ For example, Bahmani-Oskooee and Alse (1993, p540) pointed out the danger of an arbitrary choice of lag length by claiming that one must 'select a strategy for choosing the optimum number of lags on each other when there is
} 
level data, where the more productive firms are more likely to become exporters (Bernard \& Jensen, 1999; 2004). Our finding also indicates that the role of imports should be considered in the export-TFP growth link as imports also indirectly affect both exports and TFP growth.

more than one independent variable' in a VAR model. 


\section{References:}

Abramotvitz, M. (1956) Resource and Output Trends in the United States since 1870, American Economic Review, 5-23.

Ahmad, J. and Harnhirun, S. (1995) Unit Roots and Cointegration in Estimating Causality between Exports and Economic Growth: Empirical Evidence from the ASEAN Countries, Economic Letters, 49, 329-334.

Amin Gutierrez de Pineres, S. and Ferrantino, M. (1999) Export Sector Dynamics and Domestic Growth: the Case of Colombia, Review of Development Economics, 3, 268-280.

Awokuse, T. (2006) Export-led growth and the Japanese economy: evidence from VAR and directed acyclic graphs, Applied Economics, 38, 593-602.

Bahmain-Oskooee, M. and Alse, J. (1993) Export Growth and Economic Growth: An Application of Cointegration and Error Correction Modelling, Journal of Developing Areas, 27, 535-542.

Bahmani-Oskooee, M. and Miteza, I. (2002) Do Nominal Devaluations Lead to Real Devaluations in Less Developed Countries?, Economics Letters, 74, 385-391.

Balassa, B. (1978) Exports and Economic Growth: Further Evidence, Journal of Development Economics, 5, 181-189.

Ben-David, D. and Loewy, M. (2003), Trade and the Neoclassical Growth Model. Journal of Economic Integration, 18, 1-16.

Van den Berg, H. (1997) The Relationship between International Trade and Economic Growth in Mexico, North American Journal of Economics and Finance, 8, 1-21.

Bernard, A.B. and Jensen, J.B. (1999) Exporting and Productivity, NBER Working Paper, No. 7135.

Bernard, A. B. and Jensen, J. B. (2004) Exporting and Productivity in the USA, Oxford Review of Economic Policy, 20, 343-357. 
Chen, T-J. and D-P. Tang (1990) Export Performance and Productivity Growth: The Case of Taiwan, Economic Development and Cultural Change, 38, 577-585.

Coe, D. T., Helpman, E. and Hoffmaister, A.W. (1997) North-south R\&D Spillovers, Economic Journal, 107, 134-149.

Davidson, J.E.H., Hendry, D.F., Srba, F. and Yeo, S. (1978) Econometric Modelling of Aggregate Time Series Relationship between Consumer's Expenditure and Income in the United Kingdom, Economic Journal, 88, 661-692.

Diaz-Alejandro, C. (1975) Trade Policy and Economic Development in P. Kenen (ed.) International Trade and Finance: Frontiers for Research, New York, Cambridge University Press.

Dolado, J.J. and Lutkepohl, H. (1996) Making Wald Tests Work for Cointegrated VAR Systems', Econometric Review, 15, 369-386.

Edwards, S. (1993) Openness, Trade Liberalization, and Growth in Developing Countries, Journal of Economic Literature, 31, 31-57.

Engle, R.F. and Granger, C. (1987) Cointegration and Error Correction: Representation, Estimation and Testing, Econometrica, 55, 251-276.

Farrell, M.J. (1957) The Measurement of Productive Efficiency', Journal of the Royal Statistical Society, Series A, General, 120, 253-282.

Feder, G. (1982) On Exports and Economic Growth, Journal of Development Economics, 12, 5972.

Findlay, R. (1984) Growth and Development in Trade Model, in R. Jones and Kenen (eds), Handbook of International Economics (I), Amsterdam, North-Holland.

Greenaway, D., Morgan, W. and Wright, P. (1997) Trade Liberalization and Growth in Developing Countries: Some New Evidence, World Development, 25, 1885-1892. 
Greenaway, D. and Sapsford, D. (1994) What Does Liberalization Do for Exports and Growth, Weltwirschaftliches Archive, 130, 152-174.

Grossman, G. M. and Helpman, E. (1991) Innovation and Growth in the Global Economy, Cambridge, MIT Press, MA.

Harrison, A. and Hanson, G. (1999) Who Gains from Trade Reform? Some Remaining Puzzles, NBER Working Papers, No. 6915.

Helpman, E. and Krugman, P. (1985) Market Structure and Foreign Trade. Increasing Returns, Imperfect Competition and the International Economy, Cambridge MA, London: MIT Press.

Hsiao, C.W. (1987) Tests of Causality and Exogeneity between Exports and Economic Growth: the Case of Asian NICs', Journal of Economic Development, 12, 143-159.

Islam, M.N. (1998) Export Expansion and Economic Growth: Testing for Cointegration and Causality, Applied Economics, 30, 415-425.

Jin, J. (2004) On the Relationship between Openness and Growth in China: Evidence from Provincial Time Series Data, World Economy, 27, 1571-1582.

Johanson, S. (1988) Statistical Analysis of Cointegrating Vectors, Journal of Economic Dynamics and Control, 12, 231-254.

Johanson, S. and Juselius, K. (1990) Maximum Likelihood Estimation and Inference on Cointegration: With Applications to the Demand for Money, Oxford Bulletin of Economics and Statistics, 52, 169-210.

Jung, W. and Marshall, P. (1985) Exports, Growth and Causality in Developing Countries, Journal of Development Economics, 18, 1-12.

Kaldor, N. (1967) Strategic Factors in Economic Development, New York State School of Industrial and Labour Relations, Cornell University, Ithaca, NY. 
Kanamori, M. (1968) Economic Growth and Exports, in R. Klein and K. Ohkawa (eds), Economic Growth, Richard D. Irwn.

Kumbhakar, S.C. and Lovell, C.A. Knox (2000) Stochastic Frontier Analysis, New York: Cambridge University Press, p279-309.

Kwan, A.C., Cotsomitis, J.A. and Kwok, B. (1996) Exports, Economic Growth and Exogeneity: Taiwan 1953-88, Applied Economics, 28, 467-471.

Kwan, A.C., Cotsomitis, J.A. and Kwok, B. (1999) Exports, Economic Growth and Structural Invariance: Evidence from Some Asian NICs, Applied Economics, 31, 493-498

Lewer, J. and Van den Berg, H. (2003) How Large is International trade's Effect on Economic Growth, Journal of Economic Surveys, 17(3), 363-396.

Liao, H., Holmes, M., Weyman-Jones, T. and Llewellyn, D. (2006) Productivity Growth of East Asia Economies' Manufacturing: A Decomposition Analysis, Journal of Development Studies, forthcoming.

Liu, X., Burridge, P. and Sinclair, P. (2002) Relationships between Economic Growth, Foreign Direct Investment and Trade: Evidence from China, Applied Economics, 34, 1433-1440.

Lovell, Knox C.A. (1993) Production Frontiers and Productive Efficiency, in F. Harold, K. Lovell and S. Schmidt (eds.) The Measurement of Productive Efficiency, Oxford University Press, 3-67.

Lucas, R. (1988) On the Mechanics of Economic Development, Journal of Monetary Economics, $22,3-42$.

Marin, D. (1992) Is the Export-led Growth Hypothesis Valid for Industrialised Countries? Review of Economics and Statistics, 74, 678-688.

Mills, T.C. (1998) Recent Developments in Modelling Nonstationary Vector Autoregressions', Journal of Economic Surveys, 12, 279-313. 
Pack, H. (1988) Industrialization and Trade, in Chenery, H. \& T.N. Srinivasan (eds.) Handbook of Development Economics, Vol. I, Amsterdam, North Holland.

Perron, P. (1988) Trends and Random Walks in macroeconomic Time Series: Further Evidence from a New Approach, Journal of Economic Dynamics and Control, 12, 297-332.

Pesaran, M.H. and Pesaran, B. (1997) Working with Microfit 4.0: Interactive Econometric Analysis, Oxford: Oxford University Press.

Pesaran, M. H., Shin, Y. and Smith, R.J. (1996) Testing for the Existence of a Long-Run Relationship, DAE Working Paper No. 9622, Department of Applied Economics, University of Cambridge.

Pesaran, M.H., Shin, Y. and Smith, R.J. (2001) Bounds Testing Approaches to the Analysis of Level Relationships', Journal of Applied Econometrics, 16, 289-326.

Ram, R. (1987) Exports and Economic Growth in Developing Countries: Evidence from Timeseries and Cross-section Data, Economic Development and Cultural Change, 36, 51-72.

Rambaldi, A.N. and Doran, H.E. (1996) Testing for Granger non-causality in Cointegrated Systems Made Easy, Working Papers in Econometrics and Applied Statistics, Dept. of Econometric, University of New England, No. 88.

Riezman, R.G., Summers, P.M. and Whiteman, C.H. (1996) The Engine of Growth or its Handmaiden? A Time Series Assessment of Export-led Growth, Empirical Economics, 21, 77-113.

Rodrik, D. (1992) Closing the Productivity Gap: Does Trade Liberalization Really Help?, in Helleiner, G.K. (ed.), Trade Policy, Industrialization and Development: New Perspectives, Oxford University Press, Oxford. NBER Working Papers No. 2654

Rodrik, D. (1995) Getting Interventions Right: How South Korea and Taiwan Grew Rich, Economic Policy, 20, 55-107. 
Romer, P. (1993) Idea Gaps and Object Gaps in Economic Development, Journal of Monetary Economics, 32, 543-573.

Sachs, J.D. and Warner, A. (1995) Economic Reform and the Process of Global Integration, Brookings Papers on Economic Activity, 1, 1-118.

Sengupta, J. and Espana, J. (1994) Exports and Economic Growth in Asian NICs: an Econometric Analysis for Korea, Applied Economics, 26, 45-51.

Sims, C.A. (1980) Macroeconomics and Reality, Econometrica, 48, 1-48.

Thangavelu, S. and Rajaguru, G. (2004) Is There an Export or Import-led Productivity Growth in Rapidly Developing Asian Countries? A Multivariate VAR Analysis, Applied Economics, 36, 1083-1093.

Toda, H.Y. (1994) Finite Sample Properties of Likelihood Ratio Tests for Cointegrating Ranks When Linear Trends are Presen', The Review of Economics and Statistics, 76, 66-79.

Toda, H.Y. and Phillips, P.C.B. (1993) Vector Autoregression and Causality, Econometrica, 61, 1367-1393.

Toda, H.Y. and Yamamoto, T. (1995) Statistical Inference in Vector Autoregressions with Possibly Integrated Processes, Journal of Econometrics, 66, 225-250.

Tybout, J.R. (1992) Linking Trade and Productivity: New Research Directions', World Bank Research Observer, 6, 234-242.

Venables, A. (1996) Trade Policy, Cumulative Causation, and Industrial Development, Journal of Development Economics, 49, 179-197.

Vohra, R. (2001) Export and Economic Growth: Further Time Series Evidence from LessDeveloped Countries, International Advances in Economic Research, 7, 345-350.

World Bank (1993) The East Asian Miracle: Economic Growth and Public Policy, Oxford: Oxford University Press. 
Yamada, H. (1998) A Note on the Causality between Export and Productivity: an Empirical Reexamination', Economics Letters, 61, 111-114.

Yao. S. (2006) On economic growth, FDI and exports in China, Applied Economics, 38, 14664283.

Zapata, H.O. \& Rambaldi, A.N. (1997) 'Monte Carlo Evidence on Cointegration and Causation', Oxford Bulletin of Economics and Statistics, 59(2), p285-298 
Table 1: F-statistic for testing the existence of long-run relationship (ARDL)

\begin{tabular}{ll|rrr}
\hline \multicolumn{2}{l|}{ Dependant variable } & Order $(\mathrm{p}=\mathrm{q})$ & Model V & Mode III \\
\hline CHN & DTFP & 2 & 1.5287 & 3.3468 \\
& DEXPT & 1 & $6.9312^{* * *}$ & $6.5515^{* * *}$ \\
HK & DTFP & 1 & $5.4609^{? *}$ & $12.4598^{* * *}$ \\
& DEXPT & 1 & $8.3145^{* *}$ & $9.3616^{* *}$ \\
IND & DTFP & 2 & 0.2081 & 1.7206 \\
& DEXPT & 1 & $7.1198^{* * *}$ & 3.2949 \\
KOR & DTFP & 2 & $15.1038^{* *}$ & $9.1025^{* *}$ \\
& DEXPT & 1 & $5.4619^{?}$ & 3.4798 \\
MAL & DTFP & 2 & $5.9099^{* *}$ & $4.8983^{?}$ \\
& DEXPT & 1 & $5.4882^{?}$ & $5.4963^{* *}$ \\
PHL & DTFP & 1 & 3.3819 & 0.3497 \\
& DEXPT & 1 & $9.7665^{* * *}$ & $10.1832^{* * *}$ \\
SGP & DTFP & 1 & $13.8332^{* *}$ & 2.2225 \\
& DEXPT & 2 & 2.8875 & 2.8382 \\
TW & DTFP & 2 & $10.4458^{* *}$ & $11.1184^{* * *}$ \\
& DEXPT & 2 & 3.5032 & $4.4807^{?}$ \\
\hline
\end{tabular}

Notes: (1) Critical value bounds of the F-statistic [4.87 5.85] for model V and [3.79 4.85] for model III at $5 \%$ significance level.

(2) ** the null hypothesis of on long-run relationship is rejected at $5 \%$ significance level.

(3) ? the result is inconclusive as the F-statistic falls inside the band.

Table 2: Summary of ARDL Cointegration Tests

\begin{tabular}{|c|c|c|c|c|c|c|}
\hline \multirow{2}{*}{\multicolumn{2}{|c|}{ Dependent Variable }} & \multicolumn{2}{|c|}{ Using F-statistics } & \multicolumn{2}{|c|}{ Using EC representation } & \multirow[b]{2}{*}{ Conclusion } \\
\hline & & Model V & Model III & Model V & Model III & \\
\hline \multirow[t]{2}{*}{$\mathrm{CHN}$} & DTFP & $\mathrm{X}$ & $\mathrm{X}$ & & & \\
\hline & DEXPT & $\sqrt{ }$ & $\sqrt{ }$ & & & $\sqrt{ }$ \\
\hline \multirow[t]{2}{*}{ HK } & DTFP & ? & $\sqrt{ }$ & $\mathrm{X}$ & $\mathrm{X}$ & \\
\hline & DEXPT & $\sqrt{ }$ & $\sqrt{ }$ & & $\sqrt{ }$ & $\sqrt{ }$ \\
\hline \multirow[t]{2}{*}{ IND } & DTFP & $\mathrm{X}$ & $\mathrm{X}$ & & & \\
\hline & DEXPT & $\sqrt{ }$ & $\mathrm{X}$ & $\sqrt{ }$ & $\sqrt{ }$ & $\sqrt{ }$ \\
\hline \multirow[t]{2}{*}{ KOR } & DTFP & $\sqrt{ }$ & $\sqrt{ }$ & $\sqrt{ }$ & & $\sqrt{ }$ \\
\hline & DEXPT & ? & $\mathrm{X}$ & $\mathrm{X}$ & & \\
\hline \multirow[t]{2}{*}{ MAL } & DTFP & $\sqrt{ }$ & ? & & $\mathrm{X}$ & \\
\hline & DEXPT & ? & $\sqrt{ }$ & $\sqrt{ }$ & $\sqrt{ }$ & $\sqrt{ }$ \\
\hline \multirow[t]{2}{*}{ PHL } & DTFP & $\mathrm{X}$ & $\mathrm{X}$ & & & \\
\hline & DEXPT & $\sqrt{ }$ & $\sqrt{ }$ & & & $\sqrt{ }$ \\
\hline \multirow[t]{2}{*}{ SGP } & DTFP & $\sqrt{ }$ & $\mathrm{X}$ & $\sqrt{ }$ & & $\sqrt{ }$ \\
\hline & DEXPT & $\mathrm{X}$ & $\mathrm{X}$ & & & \\
\hline \multirow[t]{2}{*}{ TW } & DTFP & $\sqrt{ }$ & $\sqrt{ }$ & & & $\sqrt{ }$ \\
\hline & DEXPT & $\mathrm{X}$ & ? & & $\mathrm{X}$ & \\
\hline
\end{tabular}

Note: $\sqrt{ }$ - a long-run relationship exists; $X$ - no long-run relationship; ? - inconclusive 
Table 3: MWALD Non-Causality Tests

\begin{tabular}{|c|c|c|c|c|c|c|c|c|}
\hline & hypothesis & $\begin{array}{l}\text { With time } \\
\text { F-statistic }\end{array}$ & $\begin{array}{l}\text { constant } \\
\text { p-value }\end{array}$ & $\begin{array}{l}\text { With const } \\
\text { F-statistic }\end{array}$ & $\begin{array}{l}\text { at only } \\
\text { p-value }\end{array}$ & $\begin{array}{l}\text { Without tin } \\
\text { F-statistic }\end{array}$ & $\begin{array}{l}\text { e \& constant } \\
\text { p-value }\end{array}$ & Decision \\
\hline $\mathrm{CHN}$ & Expt $\rightarrow \mathrm{tfp}$ & $20.3348^{*}$ & 0.0000 & 0.4510 & 0.7981 & 0.5249 & 0.7692 & \\
\hline & $\mathrm{tfp} \rightarrow \operatorname{expt}$ & $30.1042 *$ & 0.0000 & $27.9621 *$ & 0.0000 & $10.8415^{*}$ & 0.0044 & $\sqrt{ }$ \\
\hline HK & expt $\rightarrow \mathrm{tfp}$ & 3.3576 & 0.1866 & 3.0167 & 0.2213 & 3.6787 & 0.1589 & \\
\hline & $\mathrm{tfp} \rightarrow \operatorname{expt}$ & $9.9760^{*}$ & 0.0068 & $15.3618 *$ & 0.0005 & 9.1600 * & 0.0102 & $\sqrt{ }$ \\
\hline IND & expt $\rightarrow \mathrm{tfp}$ & 0.1182 & 0.7310 & 0.2743 & 0.6005 & 0.2257 & 0.6348 & \\
\hline & $\mathrm{tfp} \rightarrow \mathrm{expt}$ & $10.6602 *$ & 0.0011 & $3.5837 * * *$ & 0.0584 & $6.7673 *$ & 0.0093 & $\sqrt{ }$ \\
\hline KOR & expt $\rightarrow \mathrm{tfp}$ & 2.3887 & 0.3029 & $13.3396^{*}$ & 0.0013 & $13.0261 *$ & 0.0003 & $\sqrt{ }$ \\
\hline & $\mathrm{tfp} \rightarrow \mathrm{expt}$ & $13.6509 *$ & 0.0011 & $7.2535^{* *}$ & 0.0266 & 0.0278 & 0.8673 & \\
\hline MAL & expt $\rightarrow \mathrm{tfp}$ & 4.2764 & 0.1179 & 0.8921 & 0.6401 & 0.9232 & 0.6303 & \\
\hline & $\mathrm{tfp} \rightarrow \operatorname{expt}$ & 1.3881 & 0.4996 & $7.5254 * *$ & 0.0232 & 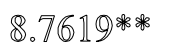 & 0.0125 & $\sqrt{ }$ \\
\hline PHL & expt $\rightarrow \mathrm{tfp}$ & 0.3065 & 0.5799 & 0.1814 & 0.6702 & 0.4222 & 0.8097 & \\
\hline & $\mathrm{tfp} \rightarrow \mathrm{expt}$ & 0.6881 & 0.9334 & 0.2093 & 0.6473 & 5.1611 米兆的 & 0.0757 & $\sqrt{ }$ \\
\hline SGP & expt $\rightarrow \mathrm{tfp}$ & 1.1277 & 0.2883 & $11.9273^{*}$ & 0.0026 & 0.4225 & 0.5157 & $\sqrt{ }$ \\
\hline & $\mathrm{tfp} \rightarrow \operatorname{expt}$ & $4.5672 * *$ & 0.0326 & 5.2464 & 0.0726 & 1.1146 & 0.2911 & \\
\hline TW & expt $\rightarrow \mathrm{tfp}$ & $25.5923 \%$ & 0.0000 & $41.0349 *$ & 0.0000 & $36.3419 *$ & 0.0000 & $\sqrt{ }$ \\
\hline & $\mathrm{tfp} \rightarrow \mathrm{expt}$ & $7.11625 *$ & 0.0074 & $7.4597 *$ & 0.0063 & $9.1492 *$ & 0.0025 & $\sqrt{ }$ \\
\hline
\end{tabular}

Note: tfp stands for productivity and expt represents for exports; the arrow in the second column shows the direction of non-causality; the last column indicates the decision: $\sqrt{ }$ means there is a causal effect. $* * *, * *$ and $*$ denote significance at the $10 \%, 5 \%$ and $1 \%$ levels, respectively. 
Table 4: Results of Causality between productivity \& export growth (the VECM approach)

\begin{tabular}{|c|c|c|c|c|c|}
\hline & & & lel V & & el III \\
\hline & hypothesis & $\sum$ (var.) & $\mathrm{EC}_{\mathrm{t}-1}$ & $\sum$ (var.) & $\mathrm{EC}_{\mathrm{t}-1}$ \\
\hline$\overline{\mathrm{CHN}}$ & expt $\rightarrow \mathrm{tfp}$ & $\begin{array}{l}2.4393 \\
(0157)\end{array}$ & $\begin{array}{l}0.8330 \\
(0.432)\end{array}$ & $\begin{array}{l}2.2834 \\
(0.172)\end{array}$ & 0.8045 \\
\hline & $\mathrm{tfp} \rightarrow \mathrm{expt}$ & 4.9102 & $2.8108 * * *$ & 0.0167 & $4.3014 *$ \\
\hline & & $(0.112)$ & $(0.067)$ & $(0.899)$ & $(0.001)$ \\
\hline HK & expt $\rightarrow \mathrm{tfp}$ & 0.0456 & 0.1479 & 0.0605 & 0.0776 \\
\hline & & $(0.956)$ & $(0.884)$ & $(0.941)$ & $(0.939)$ \\
\hline & $\mathrm{tfp} \rightarrow \mathrm{expt}$ & $4.2219^{* *}$ & $3.6787 *$ & $4.4185^{* *}$ & $3.4112 *$ \\
\hline & & $(0.032)$ & $(0.002)$ & $(0.028)$ & $(0.003)$ \\
\hline IND & expt $\rightarrow \mathrm{tfp}$ & 0.0689 & 0.2225 & 0.4083 & 0.7672 \\
\hline & 20 & $(0.796)$ & $(0.826)$ & $(0.530)$ & $(0.452)$ \\
\hline & $\mathrm{ttp} \rightarrow \operatorname{expt}$ & $\begin{array}{l}5.1150^{2+6} \\
(0.034)\end{array}$ & $\begin{array}{l}4.4307^{*} \\
(0.000)\end{array}$ & $\begin{array}{l}5.3631 \\
(0.031)\end{array}$ & $\begin{array}{l}2.8915^{\circ} \\
(0.009)\end{array}$ \\
\hline KOR & $\mathrm{expt} \rightarrow \mathrm{tfp}$ & 0.4997 & $6.4286^{*}$ & & \\
\hline & th & $\begin{array}{l}(0.613) \\
0.4894\end{array}$ & $\begin{array}{l}(0.0000) \\
29276 *\end{array}$ & & \\
\hline & нр $\Rightarrow \mathrm{Apt}$ & $(0.619)$ & $(0.007)$ & & \\
\hline MAL & $\operatorname{expt} \rightarrow \mathrm{tfp}$ & 1.0828 & 0.8034 & $3.0164 * * *$ & $2.767 *$ \\
\hline & $\mathrm{tfp} \rightarrow \operatorname{expt}$ & $2.8840^{* * * *}$ & 1.2178 & $5.1859^{*}$ & $2.5656 * *$ \\
\hline & & $(0.071)$ & $(0.242)$ & $(0.012)$ & $(0.022)$ \\
\hline PHL & $\mathrm{expt} \rightarrow \mathrm{tfp}$ & 1.3218 & 1.0542 & 1.0898 & 0.9166 \\
\hline & & & $(0.302$ & (0.306) & (0.368) \\
\hline & "1р- & $\begin{array}{l}0.0882 \\
(0.916)\end{array}$ & $\begin{array}{l}2.2902 \\
(0.032)\end{array}$ & $\begin{array}{l}0.1590 \\
(0.871)\end{array}$ & $\begin{array}{l}\text { l.4099*. } \\
(0.025)\end{array}$ \\
\hline SGP & $\operatorname{expt} \rightarrow \mathrm{tfp}$ & 2.3269 & $3.8801 *$ & & \\
\hline & & $(0.119)$ & $(0.001)$ & & \\
\hline & $\mathrm{tfp} \rightarrow \operatorname{expt}$ & $\begin{array}{l}2.9894 * * * * \\
(0.069)\end{array}$ & $\begin{array}{l}0.4443 \\
(0.661)\end{array}$ & & \\
\hline TW & expt $\rightarrow \mathrm{tfp}$ & $4.2100^{*}$ & 4.4015* & $4.0528^{*}$ & $4.2747^{*}$ \\
\hline & & $\begin{array}{l}(0.013) \\
6.9263 *\end{array}$ & $\begin{array}{l}(0.000) \\
1.708\end{array}$ & $\begin{array}{l}(0.015) \\
7.3827 *\end{array}$ & $\begin{array}{l}(0.000) \\
1.9073 * * *\end{array}$ \\
\hline & & $(0.001)$ & $(0.104)$ & $(0.001)$ & $(0.072)$ \\
\hline
\end{tabular}

Note: The arrow in the second column shows the direction of non-causality under $\mathrm{H}_{0}$. The joint significance of the coefficients is ascertained by the standard F-test. The level of significance for the error-correction term (lagged by one period) is determined by the standard t-statistics. $* * *, * *$ and $*$ denote significance at the $10 \%, 5 \%$ and $1 \%$ levels, respectively.

Table 5: Comparison of Two Causality Tests

\begin{tabular}{|c|c|c|c|c|}
\hline & \multicolumn{2}{|c|}{ VECM } & \multirow{2}{*}{$\begin{array}{c}\text { MWALD } \\
\text { L/R }\end{array}$} \\
\hline & & $\mathrm{S} / \mathrm{L}$ & L/R & \\
\hline $\mathrm{CHN}$ & $\begin{array}{l}\exp \rightarrow \text { tfp } \\
t f p \rightarrow \exp \end{array}$ & & $\sqrt{ }$ & $\sqrt{ }$ \\
\hline HK & $\begin{array}{l}\text { exp } \rightarrow \text { tfp } \\
t f p \rightarrow \exp \end{array}$ & $\sqrt{ }$ & $\sqrt{ }$ & $\sqrt{ }$ \\
\hline IND & $\begin{array}{l}\text { exp } \rightarrow \text { tfp } \\
t f p \rightarrow \exp \end{array}$ & $\sqrt{ }$ & $\sqrt{ }$ & $\sqrt{ }$ \\
\hline KOR & $\begin{array}{l}\text { exp } \rightarrow \text { tfp } \\
t f p \rightarrow \exp \end{array}$ & & $\begin{array}{l}\sqrt{ } \\
\sqrt{ }\end{array}$ & $\sqrt{ }$ \\
\hline MAL & $\begin{array}{l}\text { exp } \rightarrow \text { tfp } \\
t f p \rightarrow \exp \end{array}$ & $\begin{array}{l}\sqrt{ } \\
\sqrt{ }\end{array}$ & $\begin{array}{l}\sqrt{ } \\
\sqrt{ }\end{array}$ & $\sqrt{ }$ \\
\hline PHL & $\begin{array}{l}\text { exp } \rightarrow \text { tfp } \\
t f p \rightarrow \exp \end{array}$ & & $\sqrt{ }$ & $\sqrt{ }$ \\
\hline SGP & $\begin{array}{l}\exp \rightarrow \text { tfp } \\
t f p \rightarrow \exp \end{array}$ & $\sqrt{ }$ & $\sqrt{ }$ & $\sqrt{ }$ \\
\hline TW & $\begin{array}{l}\exp \rightarrow t f p \\
t f p \rightarrow \exp \end{array}$ & $\begin{array}{l}\sqrt{ } \\
\sqrt{ }\end{array}$ & $\sqrt{ }$ & $\begin{array}{l}\sqrt{ } \\
\sqrt{ }\end{array}$ \\
\hline
\end{tabular}




\section{Appendix A. Frontier Approach to TFP Calculation}

Total factor productivity in this paper is measured by using frontier approach. The frontier approach is capable of capturing both efficiency change and technological change as components of productivity change, while the non-frontier approach assumes the presence of full technical efficiency and technical progress. The latter is resulting from the advanced technology embodied in capital and represented by the outward shifts in the production frontier over time, which is synonymously considered to be the unique source of TFP growth. Defined this way, TFP growth derived from non-frontier approach is at best a measure of Hicks-neutral disembodied technological change and at worst nothing more than 'a measure of our ignorance' (Abramovitz, 1956). We define this so called 'best practice' function $\mathrm{f}($.$) as,$

$$
y_{i t}^{F}=f\left(x_{i t}, t\right)
$$

where $y_{i t}^{F}$ is the potential output level on the frontier at time $\mathrm{t}$ for production unit $\mathrm{i}$, given technology $\mathrm{f}($.$) , and x_{i t}$ is a vector of inputs. Take logs and totally differentiate (A.1) with respect to time to get

$$
\begin{aligned}
\dot{y}_{i t}^{F} & =\frac{d \ln f\left(x_{i t}, t\right)}{d t}=\frac{\partial \ln f\left(x_{i t}, t\right)}{\partial t}+\sum_{j} \frac{\partial \ln f\left(x_{i t}, t\right)}{\partial x_{j t}} \frac{d x_{j t}}{d t} \\
& =T P+\sum_{j} e_{j t} \dot{x}_{j t}
\end{aligned}
$$

where, variables with a dot over them represent growth rates, and the first term on the right-hand side is the output elasticity of frontier output with respect to time, defined as $\mathrm{TP}$, the second term measures the input growth weighted by output elasticities with respect to input $\mathrm{j}$, 
$e_{j}=\frac{\partial \ln f}{\partial x_{j}}=\frac{\partial \ln f}{\partial x_{j}} \frac{\partial x_{j}}{\partial \ln x_{j}}=\frac{\partial \ln f}{\partial x_{j}} x_{j}$. Note that, the conventional conceptualization of TFP growth can be defined as output growth unexplained by input growth ${ }^{12}$, i.e.

$$
\dot{T F P}=\dot{y}_{i t}^{F}-\sum_{j} \frac{w_{j t} x_{j t}}{c} \dot{x}_{j t}
$$

where, $w_{\mathrm{jt}}$ is the price of $\mathrm{j}$-th input and $\mathrm{c}$ is the total costs. Combining equation (A.2) and (A.3), one can get

$$
\dot{T F P}=T P+\sum_{j}\left(e_{j t}-\frac{w_{j t} x_{j t}}{c}\right) \dot{x_{j t}}
$$

Under the assumption of perfect competition and constant returns of scale, the output elasticities with respect to input $\mathrm{j}$ is equal to input share in the total production cost, therefore, TP is the only source of TFP growth. In case of unavailability of input price information, we follow Kumbhakar \& Lovell (2000) by assuming $\frac{w_{j} x_{j}}{c}=\frac{e_{j}}{e}$, and the decomposition in equation (A.4) simplifies to $^{13} \dot{T F P}=T P+(e-1) \sum_{j}\left(\frac{e_{j t}}{e}\right) \dot{x}_{j t}$

In the spirit of Nishimizu \& Page (1982) and further frontier analysis, any observed output $y_{i t}$ using $x_{i t}$ for inputs can be expressed as,

$$
y_{i t}=y_{i t}^{F} \exp \left(-u_{i t}\right)=f\left(x_{i t}, t\right) \exp \left(-u_{i t}\right)
$$

where $\left(-u_{i t}\right)$ is a term of output-based technical inefficiency corresponding to observed output $\mathrm{y}_{\mathrm{it}}$. The derivative of the logarithm of (A.5) with respect to time yields

$$
\dot{y}_{i t}=\frac{d \ln f\left(x_{i t}, t\right)}{d t}-\frac{d u_{i t}}{d t}=T P+(e-1) \sum_{j}\left(\frac{e_{j t}}{e}\right) \dot{x}_{j t}-\frac{d u_{i t}}{d t}
$$

\footnotetext{
${ }^{12}$ Due to the lack of data on input prices, the output elasticity with respect to input $\mathrm{j}$ is equal to input share in the total production cost under the assumption of perfect competition.

${ }^{13}$ Returns to scale can be defined as RTS $=\sum \mathrm{e}_{\mathrm{j}}$
} 
From equation (A.6), TFP growth consists of three components: technical change (innovation and shifts in the frontier technology), technical efficiency change (catching-up) and returns to scale (SEC). That is,

$$
\dot{T F P}=T P-\frac{d u_{i t}}{d t}+(e-1) \sum_{j}\left(\frac{e_{j t}}{e}\right) \dot{x}_{j t}
$$

This decomposition of TFP growth is useful in distinguishing innovation or adoption of new technology by 'best practice' production units from the diffusion of technology. Coexistence of a high rate of $\mathrm{TP}$ and a low rate of change in technical efficiency may reflect the failures in achieving technological mastery or diffusion (Kalirajan, Obwona \& Zhao, 1996). However, Nishimizu \& Page (1982, p926) ignored the presence of measurement error $\left(v_{i t}\right)$ in estimating the parameters of the translog approximation to equation (A.5) by using a deterministic frontier. In this study, we are going to estimate equation (A.5) allowing for $v_{i t}$, a symmetric component capturing random variation across production unit and random shocks that are external to its control, into the composed error term with an attempt to distinguish the effects of statistical noise from those of inefficiency so as to obtain consistent and efficient estimates. 


\section{Appendix B}

Table 1B Error Correction Representation of ARDL Model

\begin{tabular}{|c|c|c|c|c|c|c|c|c|c|c|}
\hline \multirow{2}{*}{\multicolumn{2}{|c|}{$\begin{array}{l}\text { Dependent } \\
\text { variable }\end{array}$}} & \multirow{2}{*}{$\begin{array}{l}S / R \\
\text { forcing }\end{array}$} & \multicolumn{4}{|c|}{ Model V } & \multicolumn{4}{|c|}{ Model III } \\
\hline & & & $\mathrm{k}=0$ & $\mathrm{k}=1$ & $\mathrm{k}=2$ & $\mathrm{EC}_{\mathrm{t}-1}$ & $\mathrm{k}=0$ & $\mathrm{k}=1$ & $\mathrm{k}=2$ & $\mathrm{EC}_{\mathrm{t}-1}$ \\
\hline \multirow[t]{4}{*}{$\mathrm{CHN}$} & DTFP & dexpt & 0.0052 & -0.0106 & -0.0070 & -0.8420 & -0.001 & 0.0026 & & -0.1993 \\
\hline & & & (0.8758) & (0.8754) & (1.1029) & (1.3683) & $(0.6375)$ & $(0.6462)$ & & (1.8816) \\
\hline & DEXPT & $\mathrm{dtfp}$ & 52.9557 & -18.0087 & -73.3377 & -4.3955 & 29.4230 & & & -3.3100 \\
\hline & & & $(0.8758)$ & (3.7818) & (2.3166) & $(7.1234)^{*}$ & $(0.9865)$ & & & $(3.4093)^{*}$ \\
\hline \multirow[t]{4}{*}{ HK } & DTFP & dexpt & 0.0004 & & & 3.0563 & 0.0004 & & & 2.6515 \\
\hline & & & $(1.2559)$ & & & $(3.7847)$ & (1.155) & & & (4.0484) \\
\hline & DEXPT & $\mathrm{dtfp}$ & 134.9978 & & & -1.7415 & 152.0988 & & & -1.7518 \\
\hline & & & $(3.0602)$ & & & $(6.1653)^{*}$ & $(4.0855)$ & & & $(6.2875)^{*}$ \\
\hline \multirow[t]{4}{*}{ IND } & DTFP & dexpt & 0.0099 & -0.0103 & -0.0060 & -1.044 & 0.0050 & & & 0.1179 \\
\hline & & & $(2.5552)$ & (1.9781) & (1.8928) & $(1.8260)$ & (1.5558) & & & $(2.7557)$ \\
\hline & DEXPT & dtfp & 22.1974 & 66.1577 & -111.025 & -2.1533 & 15.1431 & 76.4854 & -141.12 & -1.6942 \\
\hline & & & $(2.2738)$ & (2.1754) & $(3.1835)$ & $(7.5221)^{*}$ & (1.3404) & $(2.1131)$ & (3.553) & $(6.0715)^{*}$ \\
\hline \multirow[t]{4}{*}{ KOR } & DTFP & dexpt & -0.0001 & & & -0.3912 & 0.0002 & -0.0008 & -0.0004 & 0.0002 \\
\hline & & & $(0.6823)$ & & & $(3.1198)^{*}$ & $(1.0865)$ & $(2.9232)$ & (1.945) & $(0.0022)$ \\
\hline & DEXPT & $\mathrm{dtfp}$ & -142.08 & 251.56 & 124.41 & -0.3661 & 279.41 & & & -1.000 \\
\hline & & & $(0.7933)$ & $(2.7977)$ & $(2.5289)$ & $(0.4781)$ & $(1.8130)$ & & & \\
\hline \multirow[t]{3}{*}{ MAL } & DTFP & dexpt & 0.0024 & 0.0014 & 0.0020 & -0.1995 & 0.0012 & 0.0046 & 0.0028 & -0.0001 \\
\hline & & & $(2.3042)$ & $(0.7201)$ & (2.1130) & $(2.446)$ & (1.1017) & $(2.5675)$ & $(2.780)$ & $(0.0042)$ \\
\hline & DEXPT & dtfp & 66.3934 & & & -1.8086 & 4.9733 & & & -1.6198 \\
\hline \multirow{4}{*}{ PHL } & DTFP & dexnt & $(2.4143)$ & & & $(7.9809)^{*}$ & (1.4151) & & & $(6.7408)^{*}$ \\
\hline & TIIT & dexpl & $(0.2117)$ & & & $\begin{array}{l}-0.4200 \\
(2.8132)\end{array}$ & $(0.0475)$ & & & $(0.2199)$ \\
\hline & DEXPT & dtfp & -31.8002 & & & -1.6684 & -0.7139 & & & -1.6432 \\
\hline & & & $(0.3200)$ & & & $(6.3104)^{*}$ & $(0.7284)$ & & & $(6.6448) *$ \\
\hline \multirow[t]{3}{*}{ SGP } & DTFP & dexpt & 0.0003 & -0.0007 & & -0.6390 & 0.0025 & -0.0043 & & 0.0104 \\
\hline & & & $(0.2450)$ & (1.8173) & & $(3.3277)^{*}$ & (1.5079) & $(3.2703)$ & & (1.065) \\
\hline & DEXPT & $\mathrm{dtfp}$ & $\begin{array}{l}-116.8951 \\
(1.7289)\end{array}$ & & & -1.0000 & $\begin{array}{l}3.7794 \\
(1.4401)\end{array}$ & & & -1.0000 \\
\hline \multirow[t]{3}{*}{ TW } & DTFP & dexpt & 0.0083 & -0.0471 & -0.0133 & -0.3171 & 0.0099 & -0.0488 & -0.0132 & -0.2597 \\
\hline & & & $(0.9835)$ & (3.1549) & (1.8028) & $(3.5784)^{*}$ & (1.2418) & $(3.3479)$ & (1.815) & $(6.1791)^{*}$ \\
\hline & DEXPT & $\mathrm{dtfp}$ & $\begin{array}{l}6.1095 \\
(1.6171)\end{array}$ & $\begin{array}{l}-4.6426 \\
(1.5388)\end{array}$ & & -1.000 & $\begin{array}{l}8.1239 \\
(2.5169)\end{array}$ & $\begin{array}{l}-4.73 \\
(1.5669)\end{array}$ & & -1.000 \\
\hline
\end{tabular}

As the estimates of the error correction representation selected by AIC and SBC are very similar, we only report the results of the models selected by AIC. Number inside the parenthesis is the absolute value of the t-ratio.

* represents $5 \%$ significant

Table 2B Estimated long-run coefficients

\begin{tabular}{|c|c|c|c|c|c|c|c|c|c|c|}
\hline \multicolumn{2}{|c|}{$\begin{array}{l}\text { Dependent } \\
\text { variable }\end{array}$} & \multicolumn{5}{|c|}{ Model V underlying ARDL } & \multicolumn{4}{|c|}{ Model III underlying ARDL } \\
\hline $\mathrm{CHN}$ & Expt & $(3,3,3)$ & $\begin{array}{l}25.994 \\
(4.6076)\end{array}$ & $\begin{array}{l}0.5412 \\
(6.0447)\end{array}$ & $\begin{array}{l}-16.834 \\
(4.2169)\end{array}$ & $\begin{array}{l}-1.3311 \\
(4.2884)\end{array}$ & $(3,0,3)$ & $\begin{array}{l}8.889 \\
(1.0531)\end{array}$ & $\begin{array}{l}0.4412 \\
(2.6728)\end{array}$ & $\begin{array}{l}-55.290 \\
(0.8585)\end{array}$ \\
\hline HK & Expt & $(0,0,0)$ & $\begin{array}{l}-16.0056 \\
(0.6838)\end{array}$ & $\begin{array}{l}0.915 \\
(2.3385)\end{array}$ & $\begin{array}{l}46.2372 \\
(0.7187)\end{array}$ & $\begin{array}{l}-0.1274 \\
(0.9209)\end{array}$ & $(0,0,0)$ & $\begin{array}{l}-10.126 \\
(0.4511)\end{array}$ & $\begin{array}{l}0.9467 \\
(9.1187)\end{array}$ & $\begin{array}{l}27.9211 \\
(0.4581)\end{array}$ \\
\hline IND & Expt & $(3,3,1)$ & $\begin{array}{l}27.8176 \\
(3.0146)\end{array}$ & $\begin{array}{l}0.7933 \\
(4.4082)\end{array}$ & $\begin{array}{c}-16.1388 \\
(1.8546)\end{array}$ & $\begin{array}{l}-4.2956 \\
(3.2724)\end{array}$ & $(3,3,1)$ & $\begin{array}{l}-2.0688 \\
(1.2527)\end{array}$ & $\begin{array}{l}1.2331 \\
(5.8912)\end{array}$ & $\begin{array}{l}8.5152 \\
(1.6437)\end{array}$ \\
\hline KOR & TFP & $(3,0,3)$ & $\begin{array}{l}-0.0003 \\
(0.7782)\end{array}$ & $\begin{array}{l}-0.0038 \\
(2.1254)\end{array}$ & $\begin{array}{l}5.9011 \\
(183.4289)\end{array}$ & $\begin{array}{l}-0.0032 \\
(3.6254)\end{array}$ & & & & \\
\hline MAL & Expt & $(2,1,0)$ & $\begin{array}{l}18.5859 \\
(3.0771)\end{array}$ & $\begin{array}{l}0.3285 \\
(4.4782)\end{array}$ & $\begin{array}{l}-49.3962 \\
(2.8311)\end{array}$ & $\begin{array}{l}-0.8849 \\
(2.5176)\end{array}$ & $(2,0,0)$ & $\begin{array}{l}3.0702 \\
(1.4795)\end{array}$ & $\begin{array}{l}0.3206 \\
(3.5411)\end{array}$ & $\begin{array}{l}-4.4071 \\
(0.5606)\end{array}$ \\
\hline PHL & Expt & $(2,0,0)$ & $\begin{array}{l}-19.0608 \\
(0.3246)\end{array}$ & $\begin{array}{l}0.3567 \\
(2.6098)\end{array}$ & $\begin{array}{l}-89.3058 \\
(0.3022)\end{array}$ & $\begin{array}{l}5.4254 \\
(0.3172)\end{array}$ & $(2,0,0)$ & $\begin{array}{l}-0.4345 \\
(0.7365)\end{array}$ & $\begin{array}{l}0.3694 \\
(2.8206)\end{array}$ & $\begin{array}{l}4.4463 \\
(2.4658)\end{array}$ \\
\hline SGP & TFP & $(1,2,0)$ & $\begin{array}{l}0.0006 \\
(0.2604)\end{array}$ & $\begin{array}{l}-0.001 \\
(0.4856)\end{array}$ & $\begin{array}{l}5.0916 \\
(105.7088)\end{array}$ & $\begin{array}{l}-0.0686 \\
(85.959)\end{array}$ & & & & \\
\hline TW & TFP & $(2,3,2)$ & $\begin{array}{l}0.2897 \\
(2.6354)\end{array}$ & $\begin{array}{l}-0.0903 \\
(1.3321)\end{array}$ & $\begin{array}{l}1.5706 \\
(0.5667)\end{array}$ & $\begin{array}{l}-0.0695 \\
(0.8954)\end{array}$ & $(2,3,2)$ & $\begin{array}{l}0.3799 \\
(6.6151)\end{array}$ & $\begin{array}{l}-0.1255 \\
(1.8362)\end{array}$ & $\begin{array}{l}-0.8946 \\
(1.7879)\end{array}$ \\
\hline
\end{tabular}

